\title{
Financial Sector Development and Open Economy for Income Inequality Reduction: A Panel Fixed Model Analysis
}

\author{
Ngwen Ngangué ${ }^{1}$ \\ 1 Department of Economics, Faculty of Economic and Management, University of Yaoundé II, Yaoundé, \\ Cameroon
}

Correspondence: Ngwen Ngangue, Department of Economics, Faculty of Economic and Management, University of Yaoundé II, Po Box 1365 Yaoundé, Cameroon, Tel: 237-6-7737-9901. E-mail: ngwenn@yahoo.fr

Received: November 10, 2019

Accepted: February 27, 2020

Online Published: March 10, 2020

doi:10.5539/ijef.v12n4p33

URL: https://doi.org/10.5539/ijef.v12n4p33

\begin{abstract}
This study utilizes a panel fixed model to analyze the impact of financial sector development and commercial openness on income disparity of 40 developing countries over the period between 1995 and 2016. The empirical results suggest that there is a relationship between financial sector development, trade openness and income inequality. We establish that, in Latin America, the financial sector development increases income inequality while in Subsaharian Africa, we show the existence of an inverted U-shaped relationship between financial development and income inequality. Trade openness increases income inequality in the 40 selected countries. The increasing of 1 percent of trade openness leads the rise of 0,077 and 0,068 percent of income inequality in Latin America and Subsaharian Africa respectively. To alleviate income inequality, the government should (1) more develop financial sector and socially wide-ranging over period, important to welfares for both the rich and poor, and (2) diversify its commercial and industrial base beyond primary products in order to export high value-added products to generate more resources, better distribute them between rich and poor, and create more job opportunities.
\end{abstract}

Keywords: financial sector development, trade openness, income inequality, panel fixed model analysis

JEL Classifications: C23, D31, F41, G14.

\section{Introduction}

After the financial crisis, many researchers have started paying more attention on the increasing of income inequality over the world. According to the OECD report from November 2016, the level of income inequality remains many high in many countries despite declining unemployment and improving employment rates. Several factors might have contributed to exacerbate this phenomenon: reduced role of labor union (Diamond, 2016); globalisation and technology (Jaumotte et al., 2013); structural change (Kum, 2008); executives.bonus and compensation (Bakija et al., 2012; Kaplan \& Rauh, 2010); skill biased technological change; tax and transfer system (Denk \& Cazenave-Lacroutz, 2015). But this study focuses on others possible determinants of income inequality. May financial sector development and trade openness play a role in explaining the evolution of income inequality?

In the literature, the concept of financial development has evolved during this last decades. In 1973, Shaw defined it as the accumulation of financial assets at a faster rate than the accumulation of non-financial assets. Levine, in 2005, improved the definition of this concept and considered that these is financial development when financial instruments, markets and financial intermediaries reduce the costs of obtaining the information, contract execution costs and transaction costs. Through five functions, Levine (1997) has showed that financial development improves growth by providing the efficient allocation of capital and reducing borrowing and financing transaction costs/constraints.

In the same way, Mishkin (2007) has showed that financial system consists of institutions and markets that interact, typically in a compound manner, for the purpose of mobilizing funds for investment and providing facilities, including payment systems, to finance commercial activities. Much more, as the World Bank (1989) has described, the purpose of a financial system is to simplify the transference of savings from surplus sectors to deficit sectors. The surplus sectors include savings while the deficit sectors refer to the entrepreneurs and 
government directed out of their own savings.Recently, Fernández and Tamayo (2017) define financial development as the process by which financial system improve (or eventually overcome) information and enforcement frictions, as well transaction costs, in order to facilitate trade, mobilize savings and diversify risk.

According to the literature, the relation between financial development and income inequality is based on the three following hypotheses: broadening suggestion, finance-inequality thinning suggestion, and finance-inequality reversed U-shaped suggestion. The first two proposed suggestions are derived from the conceptual background of Banerjee and Newman (1993) and Galor and Zeira (1993), while the third suggestion was postulated from the theoretical frameword of Greenwood and Jovanovich (1990).

The finance-inequality broadening hypothesis exposes that financial development benefits only to wealthy individuals when the quality of institutions is not robust. This hypothesis further proposes financial development is profitable to the rich due to their credit-worthiness to the banks. In that conditions, income inequality increases.

The finance-inequality thinning hypothesis suggests that the poor can now get access to banks credits due to the broad presence of financial development. The accessibility of poor to better education that can help them improving their labour productivity. Doing so, financial development increases income distribution of poor and is considered as a potential mechanism in a process of reducing poverty for some countries in transition (Jalilian \& Kirkpatrick, 2002). Honoban (2004), Beck et al. (2004, 2007), Stijn and Perotti (2007) obtained the similar results.

The third hypothesis developed by Greenwood and Jovanovich (1990) shows that the early phases of financial development increases inequality, and this eventually peaks, afterwards disparity decreases once the financial sector tends to mature. This explains the presence of an inverted U-shaped hypothesis between financial development and income inequality. Tan and law (2012), Ling and Xia (2012) obtained the similar results respectively in the cases of developing countries and China.

Reviewing the existing literature on openness shows that there is not a clear definition of trade openness. According to some authors, trade openness implicitly refers to trade policy orientation and what they are interested in is to assess the impact of trade policy or trade liberalization on some economic phenomenon. For other authors however, trade openness is a more complex notion covering not only the trade policy orientation of countries but also a set of other domestic policies (such as macroeconomic policies or policies related to law and institutions for instance) which altogether make the country more or less outward oriented. In this study, we are interested to the relationship between trade openness and income inequality.

The literature related on the nexing of trade openness and financial inequality is wideworld important and debatable theoreticaly and empiricaly. In a previous study with 51 countries, Jaumotte et al. (2013) show that trade liberalization is source of disparity. Trade openness builts a competitive environment bringing economic growth, development and poverty reduction in developing countries (Ben-David \& Winters, 2000; Santarelli \& Figini, 2002). Ravallion (2004) founds that trade liberalization positivily impacted poverty reduction and income inequality if the effects of exchange are pro-poor in developing countries. Krugman and Lawrence (1993) find that trade liberalization generates new revenue or income inequality reduction in developing countries. Liberalizing trade in developing countries, coupled with increasing of economy integration in the global economy, permits to attract inward foreign direct investments (FDI) and to create new jobs for skilled workers. Using of foreign technology improves the demand for skilled workers, generating wage inequality between skilled and unskilled workers in developing countries (Zhu \& Trefler 2005; Dreher et al., 2008). Levine (2012) provides an international comparative literature across countries related on the effects of the mobility of income distribution. As far as regional inequality is concerned, Wang et al. (2008) find the increasing impacts of commercial openness and financial development on regional inequality with the case of China. Ravallion (2004) proposes that inequality in developing countries decline because of the increasing demand of the unskilled workforce.

More recently, using broader databases and cross-section or panel-data estimations, Chang et al. (2009) and Freund and Bolaky (2008) also show that trade openness has a positive effect on income and that this positive relationship is enhanced by complementary policies. The mixed impacts of commercial openness on income disparity are found in a panel study by Calderon and Chong (2001), indicating that trade openness ameliorates income inequality in developed countries and deteriorates income distribution in the case of developing countries. Similar findings are reported by Aradhyula et al. (2007). On the other hand, using generalized least squares (GLS), Tchouassi et al. (2018) have shown that trade policy positively affects economic development and thereby reduces income inequality in Central African Countries. 
It is important here to examine the relationship between financial sector development, trade openness and income inequality.

The last forty years have also witnessed the growth and spread of new technology as well as trade and financial liberalization across the world. Both of these are seen as conduits of growth but their implications for income distribution are less clear-cut.

A recent study by Jaumotte, Lall and Papageorgiou (2008) suggested that while technological change has been a significant driver of the rise in inequality across both developed and developing countries, the contribution of globalization has been relatively minor. This is because trade liberalization generally results in a reduction in income inequality while financial liberalization generally results in an increase in income inequality. Thus the effects of globalization in trade and finance on income inequality tend to offset each other.

Those studies treated the relationship between financial development, trade openness and income inequality. Kai and Hamori (2009) examine the relationship between globalization, financial deepening, and inequality in sub-Saharan Africa between 1980 and 2002. They find that openness (trade and financial liberalization) is detrimental for income inequality but this outcome is contingent to the level of development reached. They also find that financial depth reduces inequality. Similarly to Kai and Hamori (2009), Batuo and Basungo (2015) apply dynamic panel data technique to investigate the effect of liberalisation policies on income distribution for a sample of 26 African countries from 1996 to 2010. They find that financial liberalization tends to escalate income inequality both for de jure and de facto measures of financial openness.

The objective of this paper is to analyze the relationship between financial sector development, trade openness and income inequality, by investigating if financial sector development and trade openness contribute or not to reduce income inequality.

The organization of the paper is as follows. Section 2 presents the methodology and describes the econometric model, the variables, the descriptive statistics, and the data sources. The empirical results are presented in section 3. Section 4 presents the study's conclusion and policy implication.

\section{Methodology: Econometric Model, Variables, Descriptive Statistics and Data Sources}

\subsection{Econometric Model}

We have collected observations for 40 developing countries (Note 1) over the period between 1995 and 2016. We utilize a panel data estimation methods. Since in this paper, the objective is to analyze the relationship between financial sector development, trade openness and income inequality. We use income inequality as the dependent variable, financial sector development, trade openness and several other variables as explanatory variables. In static setting, the panel equation is as followed:

$$
\begin{aligned}
& \text { LOG }_{-} \text {GINI }_{i t}=\gamma+\beta_{1} L_{\text {OOG }} \text { CREDIT }_{i t}+\beta_{2} L O G_{-} C_{\text {CREDIT }}^{2}+\beta_{3} \text { OPEN }_{i t} \\
& +\sum_{k=4}^{n} \beta_{k} X_{k_{i, t}}+\eta_{i}+v_{k}+\varepsilon_{i t}
\end{aligned}
$$

From the equation above, $i$ is for country and $t$ for year. GINI is dependent variable representing the income inequality. CREDIT is one of the independent variables which capture the financial sector development. OPEN is another independent variables representing the trade openness. $\mathrm{X}$ are other independent variables included in the regression, $\eta$ and $v$ represent the country and period of fixed-effects, respectively. $\varepsilon$ represents the disturbance term.

\subsection{Variable Selections and Data Sources}

All variables and data sources are presented in the following table. 
Table 1. Variables and data sources

\begin{tabular}{|c|c|c|}
\hline Variables & Définition & Source \\
\hline GINI & $\begin{array}{l}\text { The Gini coefficients. It measures income inequality. It value is } \\
\text { move from }-1 \text { to }+1 \text {. }\end{array}$ & $\begin{array}{l}\text { Standardized World Income in Quality Data Base, } \\
\text { World Bank, Development Research Group }\end{array}$ \\
\hline CREDIT & $\begin{array}{l}\text { Internal credit provided by bank to private sector (as a } \\
\text { percentage of GDP). It measures the financial sector } \\
\text { development. The expected sign of that variable is ambiguous. }\end{array}$ & $\begin{array}{l}\text { International Monetary Fund, International } \\
\text { Financial Statistics and data files, and World Bank } \\
\text { and OECD GDP estimates. }\end{array}$ \\
\hline GDP & $\begin{array}{l}\text { GDP growth rates. The sign of that variable is expected to be } \\
\text { negative since an increase in growth would be wealth improving } \\
\text { and then reduce income inequality in presence of an efficient } \\
\text { state redistributive policy. The sign would be positive otherwise. }\end{array}$ & $\begin{array}{l}\text { World Bank national accounts data, and OECD } \\
\text { National Accounts data files. }\end{array}$ \\
\hline INVEST & $\begin{array}{l}\text { Gross fixed capital formation (as a percentage of GDP). The } \\
\text { expected sign is negative }\end{array}$ & $\begin{array}{l}\text { World Bank national accounts data, and OECD } \\
\text { National Accounts data files. }\end{array}$ \\
\hline INFL & $\begin{array}{l}\text { Measured by the growth rate of the consumer price index. The } \\
\text { expected sign remains undetermined and depends of the } \\
\text { inflationary pressure nature: supply-driven or demand-driven } \\
\text { (e.g.Blinder and Esaki, } 1978 \text { and Buse, 1982). }\end{array}$ & $\begin{array}{l}\text { International Monetary Fund, International } \\
\text { Financial Statistics and data files. }\end{array}$ \\
\hline OPEN & $\begin{array}{l}\text { measured by the sum of exports and imports as a share of GDP. } \\
\text { Trade captures the degree of openness. According to previous } \\
\text { studies, the impact of trade on the Gini coefficient is uncertain as } \\
\text { asserted by Beck et al (2007) }\end{array}$ & $\begin{array}{l}\text { World Bank national accounts data, and OECD } \\
\text { National Accounts data files. }\end{array}$ \\
\hline TRANSFER & $\begin{array}{l}\text { Volume of transfer from migrants to their countries (in GDP } \\
\text { percent). The expected sign is negative. }\end{array}$ & $\begin{array}{l}\text { International Monetary Fund, Balance of } \\
\text { Payments Statistics Yearbook and data files. }\end{array}$ \\
\hline TAX & $\begin{array}{l}\text { Value of taxes represented by the overall rate of taxes as a } \\
\text { percentage of commercial profits (in \%). The expected sign can } \\
\text { be positive or negative. }\end{array}$ & $\begin{array}{l}\text { International Monetary Fund, Government } \\
\text { Finance Statistics Yearbook and data files. }\end{array}$ \\
\hline UNEMPLWOM & $\begin{array}{l}\text { Female unemployment rate as percentage of female labor force } \\
\text { (in \%). The expected sign is positive. }\end{array}$ & $\begin{array}{l}\text { International Labour Organization, ILOSTAT } \\
\text { database }\end{array}$ \\
\hline HUMCAP & $\begin{array}{l}\text { proxied by gross secondary school enrollment rate. The } \\
\text { coefficient of this indicator is expected to be negative since the } \\
\text { accumulation of knowledge is likely to decrease income } \\
\text { inequality. }\end{array}$ & $\begin{array}{l}\text { UNESCO Institute for } \quad \text { Statistics } \\
\text { (http://uis.unesco.org/) }\end{array}$ \\
\hline RURALPOP & $\begin{array}{l}\text { Rural population as a percentage of the total (in \%). The expected } \\
\text { sign is positive. }\end{array}$ & $\begin{array}{l}\text { United Nations Population Division. World } \\
\text { Urbanization Prospects: } 2017 \text { Revision. }\end{array}$ \\
\hline
\end{tabular}

Sources: Authors.

\subsection{Descriptive Statistics}

Descriptive statistics of all the variables is presented in Table 2 below. The statistics show that income inequality varies from 33 to $65,80 \%$ while credit provides by the bank to private sector moves from 0,41 to $98,22 \%$. Trade openness varies from 5,88 to $49,32 \%$. For all the variables, the value of mean is in between the range of minimum and maximum values.

Table 2. Statistics of variables of study

\begin{tabular}{lcccccc}
\hline Variables & $\boldsymbol{N}$ & Minimum & Maximum & Mean & Standard deviation & Coefficient of variation \\
\hline GINI & 880 & 33,00 & 65,80 & 47,38 & 6,92 & 0,15 \\
CREDIT & 880 & 0,41 & 98,22 & 24,48 & 20,04 & 0,82 \\
GDP & 880 & $-7,01$ & 16,56 & 4,29 & 3,38 & 0,79 \\
INVEST & 880 & 2,78 & 40,72 & 19,51 & 5,91 & 0,30 \\
INFL & 880 & $-3,50$ & 52,03 & 9,15 & 9,41 & 1,03 \\
OPEN & 880 & 5,88 & 49,32 & 24,88 & 7,59 & 0,31 \\
TRANSFER & 880 & 0,00 & 19,00 & 2,80 & 3,89 & 1,39 \\
TAX & 880 & 0,91 & 44,45 & 14,17 & 5,05 & 0,36 \\
UNEMPLWOM & 880 & 0,30 & 39,20 & 10,85 & 8,11 & 0,75 \\
HUMCAP & 880 & 5,13 & 99,84 & 53,10 & 28,62 & 0,54 \\
RURALPOP & 880 & 4,86 & 92,79 & 50,20 & 22,71 & 0,45 \\
\hline
\end{tabular}

Sources: Authors' calculations. 
With respect to the relative dispersion measured by the coefficient of variation, we can establish the dispersion ranking in ascending order (from the least dispersed to the most dispersed) of the variables of the study, presented in graph below. It can be seen that the most volatile and heterogeneous variables are TRANSFER and INFL and the least volatile are GINI and INVEST.

\section{Coefficient of variation}

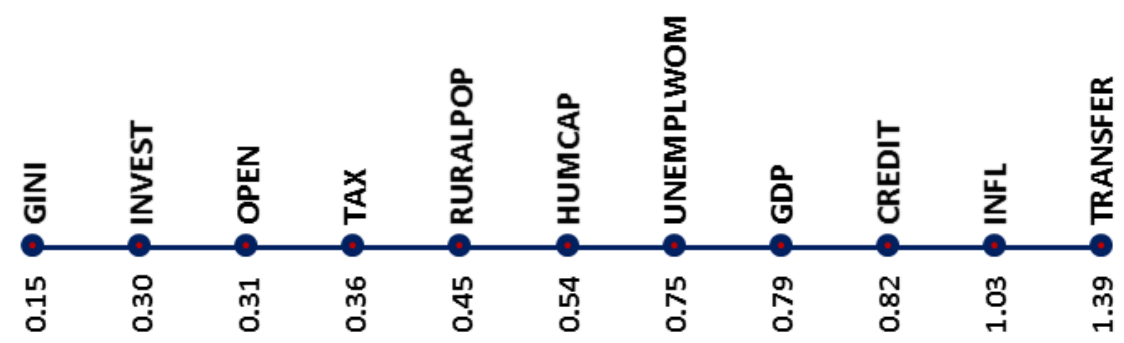

Sources: Authors' calculations.

\section{Empirical Results}

In the Table 3, we have presented stationarity test of Maddala-Wu (1999). The results of the test show that most of the variables in the study are integrated in order 1. Only the variables Log_GDP, Log_INFL and Log_UNEMPLWOM are stationary.

Table 3. Maddala and Wu (1999) Panel Unit Root test (MW)

\begin{tabular}{|c|c|c|c|c|}
\hline \multirow[t]{2}{*}{ Variables } & \multicolumn{2}{|c|}{ Lag $=0$} & \multicolumn{2}{|c|}{ Lag $=1$} \\
\hline & Sans trend & Avec trend & Sans trend & Avec trend \\
\hline \multirow[t]{2}{*}{ LOG_GINI } & 63,729 & 89,642 & 537,917 & 446,085 \\
\hline & $P=0,9086$ & $P=0,2160$ & $\mathrm{P}=0,0000$ & $\mathrm{P}=0,0000$ \\
\hline \multirow[t]{2}{*}{ LOG_CREDIT } & 112,591 & 84,479 & 473,270 & 396,960 \\
\hline & $\mathrm{P}=0,0096$ & $\mathrm{P}=0,2195$ & $\mathrm{P}=0,0000$ & $\mathrm{P}=0,0000$ \\
\hline \multirow[t]{2}{*}{ LOG_GDP } & 428,531 & 402,987 & 3605,753 & 794,996 \\
\hline & $\mathrm{P}=0,0000$ & $\mathrm{P}=0,0000$ & $\mathrm{P}=0,0000$ & $\mathrm{P}=0,0000$ \\
\hline \multirow[t]{2}{*}{ LOG_INVEST } & 91,789 & 109,362 & 600,622 & 512,760 \\
\hline & $\mathrm{P}=0,1731$ & $\mathrm{P}=0,0163$ & $\mathrm{P}=0,0000$ & $\mathrm{P}=0,0000$ \\
\hline \multirow[t]{2}{*}{ LOG_INFL } & 281,488 & 226,528 & 1588,900 & 678,730 \\
\hline & $\mathrm{P}=0,0000$ & $\mathrm{P}=0,0000$ & $\mathrm{P}=0,0000$ & $\mathrm{P}=0,0000$ \\
\hline \multirow[t]{2}{*}{ LOG_OPEN } & 94,789 & 482,089 & 606,433 & 530,431 \\
\hline & $\mathrm{P}=0,1238$ & $\mathrm{P}=0,0000$ & $\mathrm{P}=0,0000$ & $\mathrm{P}=0,0000$ \\
\hline \multirow[t]{2}{*}{ LOG_TAX } & 107,998 & 46,347 & 378,089 & 460,347 \\
\hline & $\mathrm{P}=0,0202$ & $\mathrm{P}=0,9984$ & $\mathrm{P}=0,0000$ & $\mathrm{P}=0,0000$ \\
\hline \multirow[t]{2}{*}{ LOG_TRANSFER } & 200,973 & 51,445 & 362,934 & 320,223 \\
\hline & $\mathrm{P}=0,0000$ & $\mathrm{P}=0,9946$ & $\mathrm{P}=0,0000$ & $\mathrm{P}=0,0000$ \\
\hline \multirow[t]{2}{*}{ LOG_UNEMPLWOM } & 152,283 & 298,396 & 1121,83 & 561,861 \\
\hline & $\mathrm{P}=0,0000$ & $\mathrm{P}=0,0000$ & $\mathrm{P}=0,0000$ & $\mathrm{P}=0,0000$ \\
\hline \multirow[t]{2}{*}{ LOG_HUMCAP } & 42,960 & 37,917 & 325,531 & 328,390 \\
\hline & $\mathrm{P}=0,0000$ & $\mathrm{P}=0,9999$ & $\mathrm{P}=0,0000$ & $\mathrm{P}=0,0000$ \\
\hline \multirow[t]{2}{*}{ LOG_RURALPOP } & 453,141 & 88,287 & 139,706 & 306,956 \\
\hline & $\mathrm{P}=0,0000$ & $\mathrm{P}=0,2463$ & $P=0,0000$ & $\mathrm{P}=0,0000$ \\
\hline
\end{tabular}

Sources: Authors' calculations.

The empirical results of Hausman test (table 4) suggest that we have to use fixed effect. Moreover, to check the robustness of the empirical results in different econometric specifications and to address several econometric issues, we have also conducted many regressions using alternative estimation methods (such as random effect). 
Table 4. Estimation results

\begin{tabular}{|c|c|c|c|c|c|c|}
\hline \multirow[b]{2}{*}{ Variables } & \multicolumn{2}{|c|}{ Latin America } & \multicolumn{2}{|c|}{ Subsaharian Africa } & \multicolumn{2}{|c|}{ Total } \\
\hline & Fixed Effect & $\begin{array}{c}\text { Random Effect } \\
\text { aléatoires }\end{array}$ & Fixed Effect & $\begin{array}{c}\text { Random } \\
\text { Effect }\end{array}$ & Fixed Effect & $\begin{array}{c}\text { Random Effect } \\
\text { aléatoires }\end{array}$ \\
\hline \multirow[t]{2}{*}{ Constante } & $-0,100^{* * *}$ & $-0,001^{\mathrm{ns}}$ & $-0,067^{\mathrm{ns}}$ & $-0,017^{\mathrm{ns}}$ & $-0,001^{\mathrm{ns}}$ & $-0,001^{\text {ns }}$ \\
\hline & $(0,028)$ & $(0,021)$ & $(0,047)$ & $(0,037)$ & $(0,002)$ & $(0,014)$ \\
\hline \multirow[t]{2}{*}{ LOG_CREDIT } & $0,153^{* * *}$ & $0,139 * *$ & $0,102 * * *$ & $0,084 * * *$ & $0,104 * * *$ & $0,095^{* * *}$ \\
\hline & $(0,058)$ & $(0,057)$ & $(0,027)$ & $(0,026)$ & $(0,019)$ & $(0,019)$ \\
\hline \multirow[t]{2}{*}{ LOG_CREDIT $^{2}$} & $-0,009^{\mathrm{ns}}$ & $-0,015^{*}$ & $-0,015^{* *}$ & $-0,007^{\mathrm{ns}}$ & $-0,012 * * *$ & $-0,008 * *$ \\
\hline & $(0,008)$ & $(0,008)$ & $(0,007)$ & $(0,007)$ & $(0,004)$ & $(0,004)$ \\
\hline \multirow[t]{2}{*}{ LOG_DGP } & $-0,004^{\mathrm{ns}}$ & $-0,003^{\mathrm{ns}}$ & $0,011^{\mathrm{ns}}$ & $0,015^{\text {ns }}$ & 0,003 ns & $0,005^{\text {ns }}$ \\
\hline & $(0,006)$ & $(0,006)$ & $(0,012)$ & $(0,012)$ & $(0,007)$ & $(0,007)$ \\
\hline \multirow[t]{2}{*}{ LOG_INVEST } & $0,015^{\text {ns }}$ & $0,035^{*}$ & $-0,050 * * *$ & $-0,052 * * *$ & $-0,045^{* * *}$ & $-0,045^{* * *}$ \\
\hline & $(0,020)$ & $(0,019)$ & $(0,015)$ & $(0,015)$ & $(0,012)$ & $(0,012)$ \\
\hline \multirow[t]{2}{*}{ LOG_INFL } & $-0,005^{\mathrm{ns}}$ & $-0,003^{\mathrm{ns}}$ & $-0,007^{\mathrm{ns}}$ & $-0,006^{\mathrm{ns}}$ & $-0,008$ ns & $-0,006^{\mathrm{ns}}$ \\
\hline & $(0,006)$ & $(0,006)$ & $(0,008)$ & $(0,008)$ & $(0,005)$ & $(0,005)$ \\
\hline \multirow[t]{2}{*}{ LOG_OPEN } & $0,077 * *$ & $0,019^{\text {ns }}$ & $0,068 * *$ & $0,064^{* *}$ & $0,053 * *$ & $0,049^{* *}$ \\
\hline & $(0,037)$ & $(0,032)$ & $(0,031)$ & $(0,030)$ & $(0,023)$ & $(0,022)$ \\
\hline \multirow[t]{2}{*}{ LOG_TAX } & $-0,012^{\mathrm{ns}}$ & $0,010^{\mathrm{ns}}$ & $-0,058^{* *}$ & $-0,055^{* *}$ & $-0,041 * *$ & $-0,036^{* *}$ \\
\hline & $(0,023)$ & $(0,021)$ & $(0,026)$ & $(0,023)$ & $(0,017)$ & $(0,016)$ \\
\hline \multirow[t]{2}{*}{ LOG_TRANSFER } & $0,017 *$ & $0,016^{*}$ & $-0,013^{\mathrm{ns}}$ & $-0,017^{\mathrm{ns}}$ & 0,000 ns & $-0,001^{\mathrm{ns}}$ \\
\hline & $(0,010)$ & $(0,009)$ & $(0,011)$ & $(0,011)$ & $(0,008)$ & $(0,008)$ \\
\hline \multirow[t]{2}{*}{ LOG_UNEMPLWOM } & $0,033 * * *$ & $0,037 * * *$ & $-0,011^{\mathrm{ns}}$ & $0,002^{\text {ns }}$ & $0,015^{\text {ns }}$ & $0,017 *$ \\
\hline & $(0,010)$ & $(0,010)$ & $(0,015)$ & $(0,014)$ & $(0,010)$ & $(0,009)$ \\
\hline \multirow[t]{2}{*}{ LOG_HUMCAP } & $0,142 * * *$ & $0,104 * * *$ & $-0,025^{\mathrm{ns}}$ & $-0,013^{\mathrm{ns}}$ & $0,001^{\text {ns }}$ & $0,017^{\text {ns }}$ \\
\hline & $(0,023)$ & $(0,021)$ & $(0,017)$ & $(0,016)$ & $(0,013)$ & $(0,012)$ \\
\hline \multirow[t]{2}{*}{ LOG_RURALPOP } & $-0,117 * * *$ & $0,025^{\mathrm{ns}}$ & $0,008^{\text {ns }}$ & $-0,090^{\mathrm{ns}}$ & $0,015^{\text {ns }}$ & $-0,033^{\mathrm{ns}}$ \\
\hline & $(0,039)$ & $(0,021)$ & $(0,116)$ & $(0,075)$ & $(0,051)$ & $(0,022)$ \\
\hline \multicolumn{7}{|c|}{ Caractéristiques du modèle } \\
\hline $\mathrm{N}$ & 336 & 336 & 504 & 504 & 840 & 840 \\
\hline $\mathrm{R}^{2}$ & 0,771 & 0,365 & 0,756 & 0,078 & 0,784 & 0,087 \\
\hline $\mathrm{R}^{2}$ corrigé & 0,751 & 0,344 & 0,738 & 0,058 & 0,771 & 0,075 \\
\hline Fisher & 39,965 & 16,964 & 42,643 & 3,792 & 57,390 & 7,143 \\
\hline Prob(Fisher) & 0,000 & 0,000 & 0,000 & 0,000 & 0,000 & 0,000 \\
\hline \multicolumn{7}{|c|}{ Hausman test } \\
\hline Chi2 (11) & \multicolumn{2}{|c|}{34,253} & \multicolumn{2}{|c|}{23,624} & \multicolumn{2}{|c|}{29,118} \\
\hline p-value & \multicolumn{2}{|c|}{0,000} & \multicolumn{2}{|c|}{0,014} & \multicolumn{2}{|c|}{0,002} \\
\hline Conclusion & \multicolumn{2}{|c|}{ Fixed effects } & \multicolumn{2}{|c|}{ Fixed effects } & \multicolumn{2}{|c|}{ Fixed effects } \\
\hline
\end{tabular}

Note. les valeurs des variables sont en différences premières;

Les valeurs entre parenthèses représentent les écart-types des coefficients estimés.

$\mathrm{p}<0,01 * * * ; \mathrm{p}<0,05 * * ; \mathrm{p}<0,10 * ; \mathrm{p}>0,10 \mathrm{~ns}$.

Sources: Authors' calculations.

From the table 4, we obtain that LOG_CREDIT has a positive and significant effect of income inequality. That means that the increasing of credit in the economic exacerbates income inequality in Latin America, Subsaharian Africa and in total model respectively. So, an increasing of 1 percent of credit leads respectively to, ceteris paribus, an augmentation of $0.153,0.102$ and 0.104 percent of income inequality in Latin America, Subsaharian Africa and in total model. LOG_CREDIT ${ }^{2}$ had not significant effect in Latin America, but it effect is negative and significant in Subsaharian Africa. In Subsaharian Africa, this results suggested the existence of an inverted U-shaped relationship between income inequality and financial sector development; it means inequality first increases with economic development and then decreases. In other words, in most of that countries, as industrial sector expands people engaged in industrial sector move from low income to high income. This finding corroborates the hypothesis proposed by Greenwood and Jovanovic (1990). In Latin America, the results had not confirmed the Banerjee and Newman (1993) and Galor and Zeira (1993) hypothesis. Similar findings are reported by Asongu (2013) and Haan and Sturm (2016) while Beck, Demirgüç-Kunt and Levine (2007 and 2004), Liang (2006), Bittencourt (2006), Bulir (1998), Honohan (2004), Batuo et al. (2010) obtained contrary results. 
Open had significant and positive estimated coefficient. This means that trade openness aggravates income inequality. More openness economies tend to be associated with higher level of income inequality. The increasing of 1 percent of trade openness leads the rise of 0,077 and 0,068 percent of income inequality in Latin America and Subsaharian respectively. In this countries, the benefits of trade openness have been captured by the rich at the expense of the poor. This result contrasts with that obtained by El Ghak and Zarrouk (2010).

GDP, investment and inflation have insignificant estimated coefficients. This variables have no significant effect on income inequality in that countries. Similar findings had been reported par Enowbi, Guidi et Mlambo (2010). On the other hand, this result contrast with Dollar and Kraay (2000), El Ghak and Zarrouk (2010) and Law and Tan (2009). TRANSFER, UNEMPLWOM and HUMCAP have positive and significant estimated coefficients. These results indicate that Transfer, unemployment of women and human capital increase income inequality in Latin America. RURALPOP has significant and negative estimated coefficient. This findings shows that rural population reduces inequality. The increasing of 1 percent of rural population reduces 0,0117 percent of income inequality.

\section{Conclusion}

This paper has analyzed the link between financial sector development, trade openness and income disparity. We have argued that financial development and trade openness impact income inequality. The empirical results using a panel data analysis suggest in subsaharian Africa, the existence of an inverted U-shaped relationship between financial development and income inequality proposed by Greenwood and Jovanovic (1990). This results are reported by kiendrebeogo and Minea (2016), Asongo (2013), Bahmani-Oskooee and Zhang (2014), Shehba and al. (2014), Kim et Lin (2011) and Tan et Law (2012). In Latin America, the results show that, these is a linear relationship between financial sector development and income inequality and not confirm the Banerjee and Newman (1993) and Galor and Zeira (1993) hypothesis. Indeed in Latin America, the financial sector development increases income inequality. The similar findings have been obtenained by Jauch and Watzka (2012), Fowowe and Abidoye (2013) and Zhang (2016). Trade openness increases income inequality in the 40 selected countries. The increasing of 1 percent of trade openness leads the rise of 0,077 and 0,068 percent of income inequality in Latin America and Subsaharian Africa respectively. This result contrasts with that obtained by El Ghak and Zarrouk (2010).

The most interesting economic policy recommendation of this study is that the government has to propose measures to reduce income inequality. In the sense of reducing income inequality between the rich and poor, (1) the financial institutions have to be more develop and socially inclusive over the period, to be benefits for rich and poor; (2) the economy of the selected countries also must diversify its commercial and industrial base beyond primary products in order to export high value-added products to generate more resources, better distribute them between rich and poor, and create more job opportunities; (3) practically government has to formulate new macroeconomic policies by including tax reforms and investment impetus to reduce inequality.

\section{References}

Aradhyula, S., Rahman, T., \& Seenivasan, K. (2007). Impact of international trade on income and income inequality. American Agricultural Economics Association Annual Meeting, Portland, July 29-August1, 2007. https://doi.org/10.22004/ag.econ.9999

Asongu, S. A. (2013). Investment and inequality in Africa. Which financial channels are good for the poor? The African Finance Journal, 15(2), 44-65.

Bahmani-Oskooee, M., \& Zhang, R. (2014). On the impact of financial development on income distribution: $\begin{array}{llll}\text { Time-series } \quad \text { evidence. } & \text { Applied }\end{array}$ https://doi.org/10.1080/00036846.2014.993135

Bakija, J., Cole, A., \& Heim, B. T. (2012). Jobs and income growth of top earners and the causes of changing income inequality: Evidence from US tax return data. Unpublished manuscript, Williams College.

Banerjee, A. V., \& Newman, A. F. (1993). Occupational choice and the process of development. Journal of Political Economy, 101(2), 274-298. http://dx.doi.org/10.1086/261876

Batuo, M. E., \& Asongu, S. A. (2015). The Impact of Liberalization Policies on Income Inequality in African Countries. Journal of Economic Studies, 42(1), 68-100. http://dx.doi.org/10.1108/JES-05-2013-0065

Beck, T., Demirguc-Kunt, A., \& Levine, R. (2004). Finance, inequality and poverty: cross-country evidence. Bank Policy Research Working Paper, 3338, World Bank, Washington D.C. https://doi.org/10.1596/1813-9450-3338 
Beck, T., Demirgüç-Kunt, A., \& Levine, R. (2007). Finance, inequality and the poor. Journal of Economic Growth, 12, 27-49. https://doi.org/10.1007/s10887-007-9010-6

Beck, T., Demirgüç-Kunt, A., \& Levine, R. (2009). Financial institutions and markets across countries and over time-data and analysis. https://doi.org/10.1596/1813-9450-4943

Ben-David, D., \& Winters, A. L. (2000). Trade, income disparity and poverty. World Trade Organization (WTO). Retrieved from http://hdl.handle.net/10419/107059

Bittencourt, M. M. F. (2006). Financial Development and Inequality: Brazil 1985-99. Economic Change and Restructuring, 43, 113-130. https://doi.org/10.1007/s10644-009-9080-х

Blinder, B., \& Esaki, H. (1978). Macroeconomic Activity and Income Distribution in the Postwar United States. The Review of Economics and Statistics, 60(4), 604-09. https://doi.org/10.2307/1924254

Bulir, A. (1998). Income Inequality; Does Inflation Matter? IMF Working Papers 98/7, International Monetary Fund. https://doi.org/10.5089/9781451928549.001

Buse, A. (1982). The likelihood Ratio, Wald, and Lagrange Multiplier Test: An expository Note. The American Statistician, 36(3, Part 1), 153-157. https://doi.org/10.1080/00031305.1982.10482817

Calderón, C., \& Chong, A. (2001). External sector and income inequality in interdependent economies using a dynamic panel data approach. Economics Letters, 71(2), 225-231. https://doi.org/10.1016/S0165-1765(01)00374-3

Chang, R., Kaltani, L., \& Loayza, N. V. (2009). Openness can be good for growth: The role of policy $\begin{array}{lllll}\text { complementarities. Journal of Development } & \text { Economics, } & 90, & 33-49 .\end{array}$ https://doi.org/10.1016/j.jdeveco.2008.06.011

De Haan, J., \& Sturm, J. E. (2017). Finance and income inequality: A review and new evidence. European Journal of Political Economy. https://doi.org/10.1016/j.ejpoleco.2017.04.007

Demirgüç-Kunt, A., \& Levine, R. (2009). Finance and inequality: Theory and evidence. Annu. Rev. Finance. Econ., 1(1), 287-318. https://doi.org/10.1146/annurev.financial.050808.114334

Denk, O., \& Cazenave-Lacroutz, A. (2015). Household finance and income inequality in the euro area. $O E C D$ Economic Department Working Papers, n. 1266.

Diamond, P. A. (2016). Addressing the forces driving inequality in the United States. Contemporary Economic Policy, 34(3), 403-411. https://doi.org/10.1111/coep.12184

Dollar, D., \& Kraay, A. (2000) Growth Is Good for the Poor, Development Research Group. World Bank. https://doi.org/10.1596/1813-9450-2587

Dreher, A., Gaston, N., \& Martens, P. (2008). Measuring globalization - gauging its consequences. Berlin, Germany: Springer. https://doi.org/10.1007/978-0-387-74069-0

El Ghak, T., \& Zarrouk, H. (2010) Développement financier et écarts de revenus des pays: Une analyse empirique sur données de panel. Revue Région et Développement, (32).

Enowbi, B. M., Guidi, F., \& Mlambo, K. (2010). Financial Development and Income Inequality: Evidence from African Countries. MPRA paper $N^{\circ} 25658 . \quad$ Retrieved from https://mpra.ub.uni-muenchen.de/25658/1/MPRA

Fernández, A., \& Tamayo, C. E. (2017). From Institutions to Financial Development and Growth: What are the Links? Journal of Economic Surveys, 31(1), 17-57. https://doi.org/10.1111/joes.12132

Fowowe, B., \& Babatunde, A. (2013). The Effect of Financial Development on Poverty and Inequality in African Countries. The Manchester School, 81(4), 562-585. https://doi.org/10.1111/j.1467-9957.2012.02302.x

Freund, C., \& Bolaky, B. A. (2008). Trade, Regulation and Income. Journal of Development Economics, 87(2), 309-321. https://doi.org/10.1016/j.jdeveco.2007.11.003

Galor, O., \& Zeira, J. (1993). Income distribution and macroeconomics. The Review of Economic Studies, 60(1), 35-52. https://doi.org/10.2307/2297811

Greenwood, J., \& Jovanovic, B. (1990). Financial development, growth, and the distribution of income. Journal of political Economy, 98(5, Part 1), 1076-1107. https://doi.org/10.1086/261720

Hamori, S., \& Hashiguchi, Y. (2012). The Effect of Financial Deepening on Inequality: Some International Evidence. Journal of Asian Economics, 23(4), 353-359. https://doi.org/10.1016/j.asieco.2011.12.001 
Honohan, P. (2004). Financial Development, Growth and Poverty: How Close are. Financial development and economic growth: Explaining the links. https://doi.org/10.1596/1813-9450-3203

Jalilian, H., \& Kirkpatrick, C. (2005). Does financial development contribute to poverty reduction? Journal of Development Studies, 41, 636-656. https://doi.org/10.1080/00220380500092754

Jauch, S., \& Watzka, S. (2012). Financial Development and Income Inequality: A Panel Data Approach. https://doi.org/10.1007/s00181-015-1008-x

Jaumotte, F., Lall, S., \& Papageorgiou, C. (2013). Rising income inequality: technology, or trade and financial globalization? IMF Economic Review, 61(2), 271-309. https://doi.org/10.1057/imfer.2013.7

Jaumotte, F., Subir, L., \& Papageorgiou. (2008). Rising income inequality: Technology or trade and financial globalization. IMFWorking Paper 08/185. https://doi.org/10.2139/ssrn.1175363

Kai, H., \& Hamori, S. (2009). Globalization, Financial Depth, and Inequality in Sub-Saharan Africa. Economics Bulletin, 29(3), 2025-2037. http://www.accessecon.com/Pubs/EB/2009/Volume29/EB-09-V29-I3-P51

Kaplan, S. N., \& Rauh, J. (2010). Wall Street and Main Street: What contributes to the rise in the highest incomes? Review of Financial Studies, 23(3), 1004-1050. https://doi.org/10.1093/rfs/hhp006

Kiendrebeogo, Y., \& Minea, A. (2016). Financial Development and Poverty: Evidence from the CFA Franc Zone. Applied Economics, 48, 5421-5436. https://doi.org/10.1080/00036846.2016.1176114

Kim, D. H., \& Lin, S. C. (2011). Nonlinearity in the financial development-income inequality nexus. Journal of Comparative Economics, 39, 310-325. https://doi.org/10.1016/j.jce.2011.07.002

Krugman, P., \& Lawrence, R. (1993). Trade, jobs, and wages. No. w4478, National Bureau of Economic Research. https://doi.org/10.3386/w4478

Levine, L. (2012). The US income distribution and mobility: Trends and international comparisons. CRS Report R42400. Washington, DC: Congressional Research Service.

Levine, R. (1997). Financial Development and Economic Growth: Views and Agenda. Journal of Economic Literature, 35(2), 688-726. https://doi.org/10.1596/1813-9450-1678

Levine, R. (2005). Finance and growth: theory and evidence. Handbook of Economic Growth, 1, 865-934. https://doi.org/10.1016/S1574-0684(05)01012-9

Liang, Z. (2006). Financial development and income distribution: A system GMM Panel Analysis with Application to Urban China.

Ling-Zheng, Y. U., \& Xia-Hai, W. E. I. (2012). Has financial development worsened income inequality in China? Evidence from Threshold Regression model. Journal of Finance and Economics, 3, 009. https://doi.org/10.1007/s11205-014-0801-9.

Mishkin F. S. (2007). Housing and the Monetary Transmission Mechanism. Finance and Economics Discussion Series 2007-40. Washington: Board of Governors of the Federal Reserve System, September, https://doi.org/10.3386/w13518

Perotti, R. (1996). Growth, income distribution and democracy: What the data say? JEG, 1, 149-187. https://doi.org/10.1007/BF00138861

Ravallion, M. (2004). Looking beyond averages in the trade and poverty debate. Policy Research Working Paper Series 3461, The World Bank. https://doi.org/10.1596/1813-9450-3461

Santarelli, E., \& Figini, P. (2002). Does globalization reduce poverty? Some empirical evidence for the developing countries. Working Papers 459, Universita Degli Studi di Bologna, Economia. https://doi.org/10.6092/unibo/amsacta/633

Shahbaz, M., Loganathan, N., Tiwari, A. K., \& Sherafatian-Jahromi, R. (2014). Financial Development and Income Inequality: Is There Any Financial Kuznets Curve in Iran? Social Indicators Research, 124(2), 357-382. https://doi.org/10.1007/s11205-014-0801-9

Shaw, A. S. (1973). Financial Deepening in Economic Development. New York: Oxford University Press. https://doi.org/10.2307/1238641

Stijn, C., \& Perotti, E. (2007). Finance and inequality: Channels and evidence. Journal of Comparative Economics, 35, 748-773. https://doi.org/10.1016/j.jce.2007.07.002

Tan, H. B., \& Law, S. H. (2012). Nonlinear dynamics of the finance-inequality nexus in developing countries. 
The Journal of Economic Inequality, 10(4), 551-563. https://doi.org/10.1007/s10888-011-9174-3.

Tchouassi, G., \& Tekam, O. H. (2018). Trade policy and democracy for development in Central African Countries. Journal of Empirical Studies, 5(1), 55-66. https://doi.org/10.18488/journal.66.2018.51.55.66.

Wang, B., Tian, X., \& Dayanandan, A. (2008). The Impact of Economic Globalization on Income Distribution: Empirical Evidence in China. Economic Bulletin, 4(35), 1-8.

World Bank. (1989). World Development Report. New York: Oxford University Press

Zhang, H. (2016). Wealth inequality and financial development: revisiting the symmetry breaking mechanism. Economic Theory, 63(4), 997-1025. https://doi.org/10.1007/s00199-016-0977-0.

Zhu, S. C., \& Trefler, D. (2005). Trade and Inequality in Developing Countries: A General Equilibrium Analysis. Journal of International Economics, 65(1), 21-4. https://doi.org/10.1016/j.jinteco.2003.11.005

\section{Note}

Note 1. Botswana, Burkina Faso, Burundi, Cameroon, Côte d'Ivoire, Ghana, Guinea, Guinea Bissau, Madagascar, Mali, Mozambique, Nigeria, Tanzania, Togo, Uganda, South Africa, Namibia, Zambia, Rwanda, Gambia, Congo, Kenya, Senegal, Malawi, Bolivia, Brazil, Chile, Colombia, Costa Rica, Dominican Republic, Ecuador, El Salvador, Guademalar, Honduras, Mexico, Praguya, Peru, Argentina, Venezuela, Uruguya.

\section{Copyrights}

Copyright for this article is retained by the author(s), with first publication rights granted to the journal.

This is an open-access article distributed under the terms and conditions of the Creative Commons Attribution license (http://creativecommons.org/licenses/by/4.0/). 